\title{
The Red Polybius: Otto Bauer's theory of the democratic republic ${ }^{1}$
}

\section{By Kolja Möller}

\section{Abstract}

This article reconstructs Austro-Marxist Otto Bauer's theoretical reflections on the democratic republic. It demonstrates how Bauer proceeds from the irreducible conflict around the exercise of rule as his point of departure, but also pays due attention to the impact existing legal and political forms have on scopes of articulation for antagonistic conflict. He elaborates a cycle of three stages through which the democratic republic passes: proletarian democracy, the people's republic, and an innovative conceptualization of the dictatorship of the proletariat as a backdrop for the stabilization and defence of democratic institutions. Bauer's reflections refine central concepts of political Marxism ${ }^{2}$ and relate them to democratic theory. Drawing loosely on Polybius' cycle of constitutions, Bauer can be viewed as a 'Red Polybius'. He soberly analyses the different stages of the republic and reveals how they are connected to one another. Ultimately, this article demonstrates that Bauer's work provides ample resources for theorizing the mutual interrelations and interrelatedness of social conflict and political form.

'We envisage a democratic republic.'

Otto Bauer, Demokratie und Sozialismus (1934), 105.

\section{Introduction: Political form and social conflict}

The Greek historian Polybius assumes an influential role in the history of political thought. His renowned The Histories provide a comprehensive account of the period between 264 and 164 BCE. In the sixth book of The Histories, Polybius turns to a discussion of the Roman constitution. It is here 
that he elaborates a morphology of constitutional forms, building upon the distinction between monarchy, aristocracy and democracy as developed by Plato and Aristotle. Polybius connects all three of these forms into a 'cycle of constitutional revolutions' whereby the respective modes of rule 'change', 'are transformed' and 'return again to their original stage': ${ }^{3}$ Monarchy runs the risk of collapsing into tyranny; the aristocratic rule of the 'best' may latently degenerate into an oligarchic rule of the few. Though democracy may appear as the only alternative to these outcomes, even democracy is likely to pass into an ochlocracy, i.e. a chaotic form of mob rule. Polybius' intention in sketching out this cycle is to demonstrate the superiority of the Roman republic, which relies upon a mixed constitution of the three forms, thus preventing corruptive degeneration. In the mixed constitution of the Roman republic, every element thereof is confronted with a counter-force capable of keeping it in check. The institutional arrangement of Consul, Senate and the plebeian Tribunate corresponds to a combination of monarchic, aristocratic and democratic elements and thus prevents one form of rule from becoming hegemonic over the others. In this vein, Polybius argues, the constitutional order is able to realize the common good.

It was none other than Machiavelli who returned to Polybius' cycle, albeit modifying it in one crucial aspect. Whereas Polybius was attached to a vision of republican good governance, Machiavelli interprets the cycle from a different angle. He considers the rise and fall of constitutional forms to be rooted in a perennial conflict revolving around the exercise of political rule. ${ }^{4}$ Machiavelli traces the history of political orders back to two competing attitudes - umori, or 'humours':

'Obviously, to take control of this kind of state you need the support of either the common people or the wealthy families, the nobles. In every city one finds these two conflicting political positions: there are the common people, who are eager not to be ordered around and oppressed by the noble families, and there are the nobles, who are eager to oppress the common people and order them around. ${ }^{5}$

Machiavelli combines Polybius' insights into this self-reinforcing tendency of political rule with evidence of an equiprimordial counter-force. Machiavelli goes beyond mere scrutiny of rulers' dangerous propensity for domination, identifying the non-dominating 'humours' that continually question the legitimacy of all forms of domination. Machiavelli associates this critical attitude primarily with those subjected to political rule. These two attitudes represent the two sides of a lingering conflict over political rule found at the heart of all constitutions. These two sides serve as the driving 
force behind the process of social ascent, as well as decline. ${ }^{6}$

This line of thinking has been picked up in recent years by theories of radical democracy stressing the importance and primacy of conflict over institutionalized political form. ${ }^{7}$ According to these approaches, democracy cannot be reduced to an arrangement of liberal institutions in which political elites occasionally switch places. Rather, a sound notion of democracy must acknowledge a fundamental antagonism, that is an inherent gap between those who rule and those who are ruled. Thus, the social conflict ultimately assumes primacy over existing political and legal institutions. However, this strand of thinking exhibits a lacuna in terms of the relation between social conflict and its political morphology or articulation. Specifically, the retroactive influence of existing political forms on scopes of articulation for social conflict is inadequately addressed.

In the following, I argue that we find a much richer series of deliberations on the relation between political form and social conflict in the theoretical work of the Marxist currents associated with the Vienna International (International Working Union of Socialist Parties) in the 1920s and 30s.

This article seeks to demonstrate that the theoretical reflections taken from the 'left-socialist' currents of that era provide ample resources for a more nuanced account of political rule that is sensitive to the interrelation between social conflict and political form (II.). ${ }^{8}$ It contextualizes these reflections, rooted primarily in political Marxism, with a view to democratic theory. In drawing upon the theoretical heritage of Austro-Marxism and the work of Otto Bauer (one of the current's most prominent political and intellectual figures), a theory of the democratic republic is reconstructed. Bauer distinguishes between different political phases (which I describe as 'aggregate states') characterized by specific, unique modes of articulating the social conflict (III.). While being indebted to the socialist tradition, Bauer reframes central concepts of political Marxism, most importantly the 'dictatorship of the proletariat', and brings them into line with democratic theory (IV). Finally, I demonstrate how Bauer's approach can shed a peculiar light on the contemporary crisis of western democracy (V.).

\section{Austro-Marxism}

Despite of all its economistic biases, the Marxist tradition has always addressed political concepts. Admittedly, the political and politics as such do not assume the central role in Marxism that they do in democratic theory (obscured as they are by the shadow of a course of history that is driven by a dialectic of productive forces and relations of production). But at the same 
time, recent discussions in democratic theory neglect many of the reflections emanating from the Marxist tradition devoted to politics, law and democracy. ${ }^{9}$ This lacuna is not surprising, given that the dominant currents in the workers' movement themselves carry a large portion of the responsibility for the fact that most of these resources have been either marginalized or forgotten entirely. These more nuanced approaches to the potentials and limits of democracy were superseded by the sharp opposition between Social Democratic support for a liberal republic on the one hand, and the Bolshevik model of a revolution against said republic on the other. But in the 1920s and 1930s, so-called 'left-socialist' currents emerged in continental Europe, which coalesced around a political orientation that sought to transcend the dichotomy of Social Democracy and Bolshevism. Interestingly enough, these currents contain a profound and intellectually stimulating approach to the problems of political rule, which resonates in the works of Antonio Gramsci on hegemony, in August Thalheimer's theory of fascism and Bonapartism, and spreads to the reflections of Otto Kirchheimer and Franz L. Neumann, early protagonists of the Frankfurt School..$^{10}$ In all of these attempts, we find the tendency to replace schematic oppositions such as reform and revolution, constitution and insurrection, liberalism and socialism, democracy and dictatorship with a perspective that is more attentive to real-world situations and stresses the transitions and transformations between and amongst these poles. In the following sections, this article will contextualize one of these approaches, namely the work of the Austro-Marxist Otto Bauer, from the perspective of democratic theory.

This endeavour is not without certain discontinuities, but I hope to demonstrate how Bauer's reflections on democracy and the strategy of the workers' movement stress the interrelatedness of antagonism and political form. Bauer not only emphasizes the primacy of conflict over form, but also analyses the influence of the political form on scopes of articulation of social antagonism, or conflict within the social structure itself.

Before turning to this contextualization, it would be appropriate to clarify the political and historical trajectory of the Austro-Marxist legacy. The term 'Austro-Marxism' was introduced in order to delineate a current of theoretical reflection and political strategy within the Austrian workers' movement. ${ }^{11}$ The theoretical background of Austro-Marxism emerged from the intellectual scene in Vienna. The leadership of Austrian Social Democracy was composed mainly of intellectuals who attempted to combine Marxist theory with Enlightenment philosophy, most notably that of Kant, as well as psychoanalysis and literary studies. But, however, it was not confined to intellectual reasoning. As Mozetic emphasizes in his definition, it had a threefold character: Austro-Marxism denotes an intellectual current, a 
political strategy and the welfare und cultural policies in 'Red' Vienna of the 1920s, constituting a 'way of life'. ${ }^{12}$

It was Bauer himself who elaborated this trajectory in a newspaper article from 1927. He states that - at the outset - 'the term Austro-Marxism was used to denote a group of younger, academically active comrades: Max Adler, Karl Renner, Rudolf Hilferding, Gustav Eckstein, Otto Bauer, Friedrich Adler have been the most prominent figures. This association was not driven by a specific political standpoint, but by the peculiarity of their scientific work.'13 Then, Bauer demonstrates how the term Austro-Marxism changed its meaning: After the first world war and the subsequent Austrian Revolution, it was used in order to capture the 'centrist' or 'integrative' strategy that the Austrian workers' movement pursued in the inter-war period. ${ }^{14}$ In the following, I will focus this political use of the term AustroMarxism and, more specifically, how Bauer and his followers tried to conceptualize the relation of conflict, political form and social transformation.

Contrary to most of the other European countries at the time, the Austrian workers' movement did not fracture into a debilitating schism between Social Democrats and Communists. It is especially with regard to this kind of political Austro-Marxism that Otto Bauer assumes an important place. As an intellectual educated in the Austro-Marxist tradition, he became the leader of Social Democracy in the 1920s. His strategy was devoted to the pursuit of a third way, rejecting the divide between Social Democracy and Communism.

In a first step, let us revisit the overall traits of this integrative strategy. Bauer is sceptical of the traditional, state-centric reformist strategy dominant in the European workers' movement of his time. Friedrich Engels speculated late in life about the possibility of using existing parliamentary and governmental institutions of the bourgeois state in order to introduce social reforms or even begin the construction of socialism itself. He famously stated that: 'if one thing is certain it is that our party and the working class can only come to power under the form of a democratic republic. This is even the specific form for the dictatorship of the proletariat, as the Great French Revolution has already shown. ${ }^{15}$ The Social Democratic parties interpreted these hints as a plea for a reformist strategy. They sought to gain a majority in parliamentary elections, to participate in governments und use state power in order to begin the transition to socialism. This instrumental perspective on the use of state power resonated with the right wing of Austrian Social Democracy. Karl Renner, who nowadays is mainly known for his path-breaking works on the public dimension of private law, considered state and law to be 'technical means' which could be employed 
for a vast range of ends. ${ }^{16}$ Hans Kelsen's legal theory played an important role in the political imaginary of Austrian Social Democracy. He rejected Karl Marx' fundamental critique of law and state power by invoking its affinities with anarchist (in Kelsen's view, painfully naïve) thought. Kelsen concludes his critique of Marx by making a strong case for reformism. He envisages a return to Ferdinand Lassalle's state socialism and the central role of the legislative process in reshaping society. ${ }^{17}$

Bauer is neither hostile towards these reformist ambitions nor towards participation in government as such. But he relentlessly stresses the insight that the antagonistic conflict between the ruling class and the proletariat cannot be resolved by seizing state power as a technical instrument, nor can the antagonism be entirely dissolved into institutional procedures. ${ }^{18}$ Bauer emphasizes the importance of moral and intellectual leadership by the workers' movement as a discrete 'means of government' ${ }^{19}$ He envisages, 'an as concrete as possible strategy of transformation for state, economy and society' which proceeds from an 'encompassing Social Democratic organizational structure of the social body as a whole (Durchorganisierung des Gesellschaftskörpers). ${ }^{20}$ Interestingly, this exhibits various crucial parallels to Antonio Gramsci's theory of hegemony, though Gramsci and Bauer did not engage in a direct intellectual dialogue. ${ }^{21}$ Bauer's overall approach seeks to uphold the autonomy of the workers' movement vis-à-vis other political forces or class factions as well as public institutions. Should the movement lose its capacity for initiative and cultural leadership or renounce its farreaching objectives (such as building a socialist society), its power of enforcement within the parliament and on the terrain of Realpolitik wanes concomitantly. Confronted with the interrelatedness of public institutions, ruling class forces, administrative apparatuses and property relations, Social Democracy (and the workers' movement in general) requires a strategy of transformation in which the movement does not simply collapse into a mere appendix of the existing society, degenerating into an appendage of the state apparatus. Most notably, Max Adler, though more on the left-wing of the party compared to Bauer, captured this strategy with the formula of a 'power against the state within the state': 'The proletariat can only play a powerful role in a coalition within the class-state, if it represents a power against the state, which forces the followers of the state to cooperate. ${ }^{\prime 22}$

While stressing the importance of the workers' movement autonomy, Bauer himself played the role of a centrist leader. His party managed to broaden its parliamentary representation and enter government as well. But it attempted to use its power in order to construe a 'red' lifeworld on the societal level. The exemplary case thereof is undoubtedly the heyday of 'red' Vienna in the 1920s, which was then governed by a Social Democratic 
majority. Here, Austrian social democracy enacted thoroughgoing reforms of the municipal administration, ranging from housing programmes, education and medical care to cultural networks, 'anticipating' another, socialist way of life. ${ }^{23}$ A major split between Social Democratic and Communist currents was successfully averted. Bauer's vision consisted of a 'third way' between reformist Social Democracy and Bolshevism. He highlighted an 'integral socialism', which 'rises above the contradictions of the reformist workers' movement and revolutionary socialism [...] and thereby amounts to an integrating force within a divided workers' movement. ${ }^{24}$

However, Otto Bauer distances himself from strategies of coup d'état. While rejecting a mere parliamentary strategy, he equally rejects the Russian revolution and Bolshevism as a viable mode of politics. According to Bauer, the dictatorship of the proletariat, as established in October revolution, is likely to merge into a 'dictatorship of a governmental class above the social class structure' ${ }^{25}$ Bauer seems to still be attached to the main line of thought which was typical of Marxist debate in the Second International when he postulates a certain 'ripeness' of the proletariat to be a prerequisite for a process of revolutionary social transformation. With Hans Kelsen, he argues that the dictatorship of the proletariat does not stand in contrast to the democratic republic. Rather, it denotes a stage in which the proletariat is ripe to take state power and exercise it in the 'state-form of democracy'. ${ }^{26} \mathrm{~A}$ further difference to the Bolshevik approach relates to the question of violence. Bauer rejects the brute force of violence as a means by which to erect a new society. As we will see later, most of his reflections are geared towards limiting and taming this violence.

\section{Republic}

Bauer proceeds from the primacy of social conflict over form. Being indebted to Marxist theory, he identifies the struggle between the bourgeoisie and the proletariat as the defining social conflict of his era, which he connects to already existing social actors in society, namely the organized sections of the ruling class factions and the workers' movement. ${ }^{27}$ But he goes beyond the mere fact that these conflicts assume the role of a socio-political first mover. Most importantly, in Bauer's work we find an exhaustive consideration of political forms, culminating in a sort of anacyclosis - a cycle of different aggregate states, so to speak - that the democratic republic undergoes.

Bauer's starting point is the history of the Austrian revolution in 1918. He theorizes the development of the Austrian republic by pointing out different states in which, in each respective state, social conflict, capitalist 
economy and political institutions are arranged in a specific manner. He thereby overcomes the simple binary of liberal-democratic forms and alternative models of organizing the political (e.g. via council democracy) without collapsing the democratic ideal into an elusive moment of insurrection. Bauer's perspective essentially amounts to a 'restriction analysis' which 'attempts to clarify the scopes for political action in a context of socio-political conflicts and confrontations' ${ }^{28}$ Bauer scrutinizes the relation between constraining and enabling factors of the social conflict itself. He stresses a double-movement that acknowledges the structuring impact of a given 'state' of the republic on the modalities of articulation of the social conflict, while also elucidating the transformative force of conflict with regard to existing political forms. He differentiates between three different states, which assume a central role in his history of the Austrian revolution.

\section{Aggregate State 1: Proletarian Democracy}

As was also the case in Germany's November revolution, the Austrian revolution resulted in the establishment of a parliamentary republic. In his chronicle of the revolution, Bauer traces this process back to the decisive role played by the workers' movement, the various organizations of which attain a hegemonic position in Austrian society. The movement manages to mould the mutinying soldiers into a people's army, the so-called Wehrverbände, or leagues of defence. In doing so, the workers' movement brings to bear an essential power that simultaneously contributes to the civilization and pacification of the soldiers. Bauer refuses to romanticize the revolutionary process, and is fully aware that this 'crowd would pass into a band of mercenaries had it been left to its own devices.' ${ }^{29}$ Gradually, the workers' movement broadens its organizational basis and begins to dispose over the means of violence. This does not lead to an offensive strategy aiming at the construction of a workers' state. Rather, Bauerian Social Democracy pursues a defensive strategy that avoids the exercise of violence. The transition to a socialist society cannot be instigated through the victory of a proletarian army in a civil war. Bauer fears a 'self-overcoming of the revolution itself' (Selbstaufhebung der Revolution)' ${ }^{30}$ To him, it is difficult to imagine that an emancipatory transition can emerge from war-like conflicts. Furthermore, the international balance of class forces inhibits the possibility of constructing a socialist state in Austria alone. Bauer summarizes that the 'dictatorship of the proletariat [...] would have ended in the dictatorship of an occupying army'. ${ }^{31}$ The defensive strategy does not aim to overthrow parliamentary democracy. Social Democracy enters into a coalition with conservative forces in order to maintain and safeguard the governability of the country. ${ }^{32} \mathrm{But}$ at 
the same time, the workers' movement retains its powerful position. It holds onto the means of violence via the Wehrverbände - it does not transfer control of them to the state. Although this situation could be viewed as fertile ground for a revolution in the Bolshevik fashion, the workers' movement holds fast to its defensive strategy. The dictatorship of the proletariat is used as a looming possibility that poses a perennial threat to the ruling class camp and thereby serves to instil a latent fear of revolution in the ruling class itself.

Thus, the first aggregate state of the nascent Austrian republic is characterized by 'hegemony of the working class' ${ }^{33}$ Bauer uses the concept of 'proletarian democracy' in order to describe this particular state. ${ }^{34}$ During the state of 'proletarian democracy', political and societal democracy are combined. Parliamentary democracy is supplemented with a 'functional democracy' that introduces modes of economic and council democracy, thereby extending the claim to democracy to other social spheres. ${ }^{35}$ Bauer connects this stage with republican notions and discusses the relation between the governing class and the governed. Since the governing class no longer disposes over the means of violence, it cannot repress the humours of the ruled via military means. ${ }^{36}$ It must enter into a deliberative process in order to legitimate its role in the state: 'Democracy - to the masses, this was not just a mere government by elected officials through universal suffrage, but a method of government which forced the governing class to work hard and to argue for every single act in order to gain the approval of the affected masses. ${ }^{37}$ In the state of proletarian democracy, the government relied 'only on the government of intellectual leadership, a government through the consent of the masses' ${ }^{38}$ Bauer emphasizes the function of factory assemblies in which governmental policies were discussed. He describes the 'selfeducation of the masses' and the 'arousal of initiative' which took place. ${ }^{39}$ Furthermore, Bauer refers to the promise of the American revolution: a 'system of government founded on the consent of the governed' was at least partially realized. ${ }^{40}$

The overarching thesis seems to be that the democratic republic can enter a state of proletarian democracy. Thereby, the workers' movement assumes a hegemonic role: on the one hand, it extends democracy to other social spheres, most importantly the economy, on the other hand, it brings a modicum of social peace to society by depriving the state and the ruling class of the means of violence which would otherwise be deployed to stifle the subaltern classes. The workers' movement only deploys the means of violence in a defensive manner. It does not apply them for their own sake, but merely disposes over them. Under these conditions, Bauer identifies some germs of a mode of governance whereby the government must legitimate itself through a series of deliberative processes. The power 
struggle amongst the classes - between the bourgeoisie and the proletariat as well as between the government and governed - cannot be fought with 'violent means' ${ }^{41}$ Bauer's hope is that the aggregate state of proletarian democracy will encourage the development of a tendency that can ultimately lead to a 'socialist democracy as a form of organization for a classless socialist society' founded 'on the regulative idea of a "society of the free-willing humans, an anarchic society"'. ${ }^{42}$ By doing so, he replaces the 'dictatorship of the proletariat' as the most important transitional stage towards another society with the concept of proletarian democracy - a stage which does not stand in a stark contrast to the democratic republic because it merely realizes its very principles.

\section{Aggregate State II: People's Republic}

Despite the many hopeful developments in the early days of the Austrian revolution, revolutionary furore subsided. Bauer observes a new state that he defines as the 'people's republic'. ${ }^{43}$ Democratic institutions and elements of functional democracy remain intact, but the workers' movement loses its hegemonic position. The international balance of class forces and the need for economic development thwart its powerful role: 'Industrial highconjuncture overcame the tension of the revolutionary stage. ${ }^{\prime 4}$ Politically, this is expressed in the fact that Social Democracy is forced to cooperate with the conservative camp in the second post-revolutionary coalition. ${ }^{45}$

In order to elucidate this state of affairs, Bauer borrows a theoretical concept from the late Friedrich Engels. Engels observed that, in certain historical periods, political power is shared by various class forces. This is the case "when the warring classes are so nearly equal in forces that the state power, as apparent mediator, acquires for the moment a certain independence in relation to both'. ${ }^{46}$ Bauer takes up to the concept of maintaining balance and applies it to the democratic republic. Accordingly, in the emerging people's republic a 'balance of class forces' enters the scene. It is a state in which 'neither the bourgeoisie nor the proletariat is able to dominate the state'. ${ }^{47}$ Since 'all classes of the people have a share in state power', ${ }^{48}$ the class struggle can be articulated peacefully, despite the proletariat finding itself in a more defensive position than it enjoyed during the state of proletarian democracy.

Following his reflections, the stability of the republic cannot be maintained through procedures and constitutional provisions alone (e.g. the new constitution, drafted by Hans Kelsen). The crucial point consists in the balance of class forces which prevents the republic from collapsing into a civil war or into an authoritarian state. Bauer is completely aware of the fact 
that the 'balance of class forces' is indeed a precarious terrain. ${ }^{49}$ Thus, he points out that a transformation of the republic into a proletarian democracy is by no means the only conceivable trajectory - after all, the people's republic for the most part limits itself to applying democratic principles in a more consistent manner. The major threat to the people's republic instead emanates from the possibility of authoritarian factions of the ruling class suspending the democratic republic as a whole and paving the way for fascist rule. This is the reason why Bauer's approach is devoted to ensuring that the republic does not degenerate into an instrument of the bourgeoisie. The struggle for the maintenance of democratic institutions amounts to the primary task in times of the 'proletarian defensive'..$^{50}$

Throughout the aggregate state of the people's republic, some achievements of proletarian democracy persist. The most important examples are elements of economic democracy and the relative flexibility of the constitution to allow non-capitalist modes of development. The balance of class forces induces a constitutional mindset which ultimately came to characterize the norm of the (West) European post-war order.

However, it would be misleading to restrict the people's republic to a mere conservation of the existing balance of class forces. Rather, it is through this aggregate state that social transformation is still able to play out. We should not forget that the Austro-Marxist strategy did not solely rely on a peculiar notion of conflict and democracy, but also on a theory of evolution which was heavily influenced by Marx and Darwin. ${ }^{51}$ The Austro-Marxists' hold to the idea that the immanent contradictions of the capitalist economy undergo an evolutionary drift towards social transformation. Most importantly, they assumed that - through the universalization of wage labour - the proletariat will amount to a numerical majority in society and, thereby, is able to impose its will via democratic procedures. ${ }^{52}$ Further, they assumed that the inner contradictions of the capitalist economy discharge into moments of crisis where socialism can present itself as the only viable alternative to the pursuit of a crisis ridden mode of production. And not in the least, that the anticipation of a red lifeworld in civil society should exert long-term effects on the level of social practices. ${ }^{53}$ In this sense the seemingly conservative state of compromise was a possible ground for social transformation which was supposed to evolve in its shadow. The undecided people's republic was - at least in the reflections of Bauer - not a dismissal of revolutionary aspirations.

\section{Aggregate State III: Dictatorship of the Proletariat}

Within classical Marxism, the term 'dictatorship of the proletariat' addresses 
the question of transition from bourgeois to socialist society. Most notably, it served as an umbrella term to express that which would occur after the seizure of state power, whether via parliamentary elections or armed revolution. ${ }^{54}$ Most notably, the Bolshevik tradition conceived of the dictatorship of the proletariat as a state of exception, standing in sharp contrast to the democratic republic. Bauer, however, moves in the opposite direction by introducing a notion of proletarian dictatorship consistent with the democratic imaginary. To him, it simply denotes another, third aggregate state that the republic can assume. Bauer elaborates his argument with regard to a permanent, creeping danger that exists in class society. Namely, that ruling class forces may come to reject the republican order and deploy the means of violence against the workers' movement. This scenario becomes increasingly likely as political power 'tends to fall into the hands of a workers' government which is determined to expropriate the capitalists and socialize the means of production. ${ }^{55}$ If the workers' party gains a parliamentary majority and factions of the ruling class turn to a violent coup d'état in response, then - and only then - should Social Democracy and its armed wings be mobilized to establish a dictatorship of the proletariat. ${ }^{56}$

Obviously, Bauer makes great pains to distance himself from the notion of dictatorship commonly found in classical Marxism. While Marx, as well as Social Democratic and more than anyone else Bolshevik theories of revolution view the dictatorship as a lever which to establish a new social order, Bauer assigns it a merely defensive function. It is not the counterpart to the republic. Rather, it represents a precarious stage in which crucial democratic achievements are defended 'when the bourgeois class tries to implode democracy and wraps itself in the arms of fascism. ${ }^{57}$ Here, the dictatorship is not an instrument of revolution resembling a 'locomotive of history', but more like an 'emergency brake' which prevents an authoritarian transformation. ${ }^{58}$

This line of thought even enters the Party's Linzer Programm in 1926 and is expanded into a more general strategy of defensive violence. The notion of defensive violence relates to the problem that Austrian society at the time appeared to be approaching a civil war. The central innovation of this strategy is located in the fact that, under the auspices of defensive violence, it is not the workers' movement which decides upon the use of violent means but rather its opponents in the ruling class. Should the ruling class resort to brute violence, the republikanische Schutzbund (republican defense union), aligned with Social Democracy and founded explicitly for this very purpose, is to mount a defense of the republic. ${ }^{59}$ It is here that the tragedy of Austrian Social Democracy becomes visible. In the short civil war of 1934, the Austrofascists were successful in destroying the workers' 
movement. ${ }^{60}$ This evoked, in the aftermath of defeat, harsh criticism of the concept of defensive violence and the Austro-Marxist conception of proletarian dictatorship. ${ }^{61}$ However, it is questionable if the Party's programmatic orientation or even the leadership of Otto Bauer as such can be held responsible for the defeat.

From a more theoretical perspective, it is interesting to note that the Austro-Marxist movement cultivated a unique approach to the question of violence. Not only in that it 'shows considerable deviations from the scheme of Marx and Engels', ${ }^{62}$ but also in how it neither fatalistically accepted the use of violence, nor merely repudiated it. Indebted as it was to pacifistic ideals and values, it was clear to Austrian Social Democracy that the transition to an emancipatory society could not be achieved by military means. At the same time, confronted by a latently violent constellation of social forces, it was equally impossible for Social Democracy to abandon the workers' movement to the violence of the state or ruling class forces. Thus, the cultivation of the capacity to exert violence (without using it) became the paradoxical strategy of choice. The overall approach was to intervene in the political strategy building and decision-making of the opposite, 'bourgeois' camp. The authoritarian transformation was to be toppled, but this was only possible if the decision to collapse the Austrian Republic into an authoritarian regime should, from the outset, amount to a decision about civil war and peace. By creating a sort of 'background threat' via the establishment of the republikanische Schutzbund, the workers' movement aspired to discipline the bourgeois class and raise the 'costs' in the opposite camp for aligning with the fascist alternative.

Apparently, this strategy was paradoxical:63 On the one hand, it exerted a latent background threat on the opposite camp; on the other, it pursued a peaceful and legal mode of mass politics. This was reflected in the organizational architecture and practice of the republikanische Schutzbund. It was never really prepared for entering a civil war. According to Illona Ducynska, a left communist who participated in the Schutzbund, it was 'only meant as a gesture of threat' ${ }^{64}$ This has not only a functional, but also a normative dimension. The leadership around Bauer was not really willing to make use of violent means and the 'traditionally pacifistic education kept many Social Democratic workers from joining the robust marshal organizations (wehrhafte Ordnerorganisationen). ${ }^{65}$ Even Theodor Körner, who worked as a consultant for the Schutzbund and tried (unsuccessfully) to introduce its troops to a guerilla strategy, stated that 'you cannot enter a war with an army of pacifists.' ${ }^{66}$ 


\section{Bauer's Anacyclosis}

Beyond a few isolated mentions of the American revolution, Bauer does not explicitly make reference to the classical tradition of democratic theory ${ }^{67}$ Nevertheless, we can identify some recurring motifs and, not least, an account of different aggregate states. While they are not coherently contextualized as a 'cycle', the different states are obviously part of a broader movement in which the different states are subject to both rise and fall.

Obviously, Bauer's reflections are located on a theoretical threshold straddling multiple intellectual traditions. On the one hand, Bauer shares with Kelsen and Renner an understanding of the value of democratic and legal institutions. However, he does not limit his approach to the worth of universal and impartial institutional arrangements by themselves. To Bauer, democratic institutions emerge from a balance of forces between class factions and remain closely connected to a determinate social substrate. ${ }^{68} \mathrm{On}$ the other hand, he does not dissolve the theory of the democratic republic into an over-simplified theory of class struggle. He relentlessly stresses the formative impact of the constitution and the respective aggregate states on the modalities of articulation of the social conflict. Only democratic institutions create a terrain upon which the transition to a proletarian or socialist democracy becomes a possibility, and thus may not be suspended.

Furthermore, Bauer's reflections are not restricted to proving the factual indeterminateness of subaltern humours. Rather, he soberly identifies how the critique of domination can be expressed under non-ideal circumstances, most importantly within the different aggregate states. Bauer shows clear preferences as far as these aggregate states are concerned: proletarian democracy is a necessary prerequisite for the transformation of society towards socialism; the people's republic maintains important social gains and potentially paves the way for transformative changes. It can potentially turn into either proletarian democracy or an authoritarian mode of rule. Admittedly, the corruptive tendencies latent in the people's republic are not discussed coherently, but Bauer repeatedly hints at the possibility that each stage contains the potential to degenerate into problematic variants.

This is the case when proletarian democracy escalates into a civil war; or when the people's republic degenerates to an aristocratic corporatist structure and thereby thwarts the autonomy of the workers' movement; or when the dictatorship of the proletariat, established in order to defend the republic, turns into an authoritarian order. In conclusion, the existence of the democratic republic and the morphology of aggregate states as detailed by Bauer does not prescribe a meticulous strategy for the workers' movement, be it revolutionary or reformist. An investigation into the existing 
aggregate states is however necessary in order to clarify possible courses of action and identify the central political challenges.

\section{Threat, Procedure and concentrated power}

Bauer's investigation into the different states of rule stresses that even within a democratic republic we can observe peculiar transformations and different modes of organizing political rule. While democracy remains the starting point of emancipation, an approach that focuses solely on the general republic in the most abstract sense does not provide the necessary ground for defining possible courses of action nor even for serious normative reflection. Rather, when speaking of Otto Bauer's relevance today, he should be depicted, at least when it comes to his analysis of political rule, as a 'Red Polybius' who undertakes a thorough investigation of political cycles and potentials for corruption. Bauer shows that reflections on the conditions of possibility for society and democracy alone are extremely helpful, though ultimately insufficient, in elucidating the rise and fall of political forms.

The approach provides a systematic perspective on how political forms and social power relations interrelate. It revolves around the question how and under what circumstances existing legal and political procedures can play out or incite transformative potentials or, at least, neutralize the concentration of social power. As we have seen, his answer is nuanced to the extent that he combines a procedural model of democracy with the need to challenge concentrated social power by other forms of counter-power, such as strikes, industrial democracy or lingering background threats.

In the course of the last decades, western societies have seen the growth of democratic procedures, governance participation and citizens' involvement. In democratic theory, the deliberative turn had seen its heyday. But, however, the scopes for social transformation with a view to disperse social power have either not taken place or have become narrow. Threatened by multinational companies, which assume the role of 'shadow sovereigns' as Susan George has put it, ${ }^{69}$ the most relevant policy options disappear from the regular parliamentary decision-making process, either from the outset or ex-post through visible blackmailing (as in the case of the Euro-Crisis). Furthermore, right-wing populism has managed to induce forceful background threats to democratic procedures and to articulate a distorted version of the oppositional impulse which was once, associated with the left - broadly speaking. In order to challenge this constellation, it could be useful to apply Bauer's insights: Democracy cannot be portrayed as a stable and enduring framework, but it is in constant danger of being toppled 'from above' or even undergoing an authoritarian transformation. 
If this is true, political strategy and democratic theory has to cope with the question of how to neutralize this danger.

Kolja Möller is interim professor for constitutional theory at the Technische Universität Dresden and a research fellow in the project 'Transnational Force of Law', University of Bremen. Before, he worked as a postdoctoral fellow at the cluster of excellence 'Normative Orders', University of Frankfurt. His research focuses on international political sociology, political theory and constitutional theory. Currently, he works on a comprehensive theory of populism.

His selected publications include:

Formwandel der Verfassung. Die postdemokratische Verfasstheit des Transnationalen Bielefeld: transcript-Verlag (2015); A Critical Theory of Transnational Regimes. Creeping Managerialism and the Quest for a Destituent Power, in: K. Blome, A. Fischer-Lescano, H. Franzki, N. Markard \& S. Oeter (Eds.), Contested Collisions. Interdisciplinary Inquiries into Norm Fragmentation in World Society, Cambridge: Cambridge University Press (2016) pp. 255 - 280, and 'Popular Sovereignty, Populism and Deliberative Democracy’ Philosophical Inquiry (2017, forthcoming).

\section{Bibliography}

Abendroth, W. (2008) 'Zum Begriff des demokratischen und sozialen Rechtsstaates im Grundgesetz der Bundesrepublik Deutschland' (1954) in M. Buckmiller, J. Perels, \& U. Schöler (Eds.), Gesammelte Schriften Band 2 Hannover: Offizin, pp. 338-357

Abensour, M. (2011) Democracy Against the State: Marx and the Machiavellian Moment Cambridge/Malden: Polity Press

Adler, M. (1970) 'Der Klassenkampfgedanke bei Marx' (1923) in H.-J. Sandkühler \& R. De La Vega (Eds.), Austromarxismus. Texte zu "Ideologie und Klassenkampf" Frankfurt am Main: Europäische Verlagsanstalt , pp. 140-190

Albers, D. (1979) 'Otto Bauer und des Konzept des "integralen Sozialismus"' in A. W. Arbeiterbewegung (Ed.), Eurokommunismus und Theorie der Politik Berlin: Argument-Verlag, pp. 83-102 
Albers, D. (1985) 'Anmerkungen zur Aktualität Otto Bauers und des Austromarxismus' in D. Albers, H. Heimann, \& R. Saage (Eds.), Otto Bauer Theorie und Politik Berlin: Argument-Verlag, pp. 138-145

Albers, D. (1987) 'Über den Marxismus Otto Bauers und Antonio Gramscis' in D. Albers (Ed.), Sozialismus im Westen. Erste Annäherungen: Marxismus und Sozialdemokratie Berlin u. Hamburg: Argument-Verlag, pp. 49-73

Baier, W. (2008) 'Integraler Sozialismus und radikale Demokratie' in W. Baier, L. N. Trallori, \& D. Weber (Eds.), Otto Bauer und der Austromarxismus. "Integraler Sozialismus" und die heutige Linke Berlin: Dietz-Verlag, pp. 17-31

Bauer, O. (1923) Die österreichische Revolution Wien: Wiener Volksbuchhandlung

Bauer, O. (1925) The Austrian Revolution. London: L. Parsons

Bauer, O. (1936) Zwischen zwei Weltkriegen. Die Krise der Weltwirtschaft, die Demokratie und der Sozialismus Bratislava: Eugen Prager Verlag

Bauer, O. (1970a) 'Das Gleichgewicht der Klassenkräfte' (1924) in H.-J. Sandkühler \& R. De La Vega (Eds.), Austromarxismus. Texte zu "Ideologie und Klassenkampf" Frankfurt am Main: Europäische Verlagsanstalt, pp. 79-97

Bauer, O. (1970b) 'Demokratie und Sozialismus' (1934) in H.-J. D. L. V. Sandkühler, Rafael (Ed.), Austromarxismus. Texte zu "Ideologie und Klassenkampf" Frankfurt am Main: Europäische Verlagsanstalt, pp. 98-119

Bauer, O. (1989) 'Austromarxismus' (1927) in A. Pfabigan (Ed.), Vision und Wirklichkeit. Ein Lesebuch zum Austromarxismus Wien: Löcker Verlag, pp. 1418

Bauer, O. (2000) The Question of Nationalities and Social Democracy Minneapolis/London: University of Minnesota Press

Benjamin, W. (1974) 'Notizen und Vorarbeiten zu den Thesen „Über den Begriff der Geschichte"' Gesammelte Werke I/3 Frankfurt am Main: Suhrkamp, pp. 1223-1266 
Blum, M. E., \& Smaldone, W. (Eds.) (2015) Austro-Marxism: The Ideology of Unity Austro-Marxist Theory and Strategy Volume 1. Leiden: Brill

Blum, M. E., \& Smaldone, W. (Eds.) (2017) Austro-Marxism: The Ideology of Unity. Changing the World: The Politics of Austro-Marxism Volume 2. Leiden: Brill

Bottomore, T. (1989) 'Austro-Marxist Conceptions of the Transition from Capitalism to Socialism' International Journal of Comparative Sociology 30(1-2), pp.109-120

Bottomore, T., \& Goode, P. (Eds.). (1978) Austro-Marxism: Texts Oxford: Oxford University Press

Brunkhorst, H. (2007) 'Kommentar' in H. Brunkhorst (Ed.), Karl Marx. Der achtzehnte Brumaire des

Louis Bonaparte (1. Aufl. ed.,). Frankfurt am Main: Suhrkamp pp. 133-328

Diers, A., \& Schmitz, M. (2015) Linkssozialismus Historisch-kritisches Wörterbuch des Marxismus Hamburg: Argument-Verlag, pp. 1207-1218

Draper, H. (1986) Karl Marx's Theory of Revolution: The Dictatorship of the Proletariat New York: Monthly Review Press

Duczynska, I. (1975) Der demokratische Bolschewik. Zur Theorie und Praxis der Gewalt München: List Verlag

Engels, F. (1972) 'Zur Kritik des sozialdemokratischen Programmentwurfs ' (1891) Karl Marx/Friedrich Engels - Werke Band 22 Berlin: Dietz-Verlag, pp. 225-240

Engels, F. (1975) 'Der Ursprung der Familie, des Privateigentums und des Staats' (1884) Karl Marx/Friedrich Engels - Werke Band 21 Berlin: DietzVerlag, pp. 25-173

George, S. (2015) Shadow Sovereigns: How Global Corporations are Seizing Power Cambridge/Malden: Polity Press

Gramsci, A. (1991) Gefüngnishefte - kritische Gesamtausgabe Hamburg: Argument 
Gransow, V., \& Krätke, M. (1979) 'Thesen zur politischen Theorie des Austromarxismus' in A. W. Arbeiterbewegung (Ed.), Eurokommunismus und Theorie der Politik Berlin: Argument-Verlag pp. 103-122

Hanisch, E. (2011) Der große Ilusionist Otto Bauer (1881-1938) Wien/Köln/Weimar: Böhlau-Verlag

Heidenreich, F. (1985) 'Das Linzer Programm und die Strategie des demokratischen Wegs zum Sozialismus' in D. Albers, H. Heimann, \& R. Saage (Eds.), Otto Bauer: Theorie und Politik Berlin: Argument-Verlag pp. 43-55

Kalyvas, A. (2008) Democracy and the Politics of the Extraordinary. Max Weber, Carl Schmitt and Hannah Arendt New York: Cambridge University Press

Kelsen, H. (1965) Sozialismus und Staat. Eine Untersuchung der politischen Theorie des Marxismus (1920). Wien: Wiener Volksbuchhandlung.

Kelsen, H. (1983) ‘Otto Bauers politische Theorien’ (1924) in G. Mozetic (Ed.), Austromarxistische Positionen Wien/Köln/Graz/Böhlau: Hermann Böhlaus Nachf pp. 205-215

Kirchheimer, O. (1976) 'Zur Staatslehre von Sozialismus und Bolschewismus' in W. Luthardt (Ed.), Von der Weimarer Republik zum Faschismus: Die Auflösung der demokratischen Rechtsordnung Frankfurt am Main: Suhrkamp pp. 32-52

Laclau, E. (2005) On Populist Reason London/New York: Verso.

Lefort, C. (1986) Le travail de l'oeuvre Machiavel (1972) Paris: Gallimard

Lefort, C. (1994). 'Droit de l'homme et politique' in C. Lefort (Ed.), L'invention démocratique Paris: Fayard pp. 45-83

Leser, N. (1968) Zwischen Reformismus und Bolschewismus. Der Austromarxismus als Theorie und Praxis Wien/Frankfurt/Zürich: Europa Verlag

Leser, N. (1976) 'Austro-Marxism: A Reappraisal' Journal of Contemporary History, 11(2/3), pp. 133-148

Machiavelli, N. (2000) Discorsi (1531). Frankfurt/Leipzig: Insel-Verlag 
Machiavelli, N. (2003) Il Principe (1532). Stuttgart: Reclam

Maderthaner, W. (2006) Austro-Marxism: Mass Culture and Anticipatory Socialism Austrian Studies, 14, pp.21-36.

Marx, K. (1960) ‘Die Klassenkämpfe in Frankreich 1848 bis 1850’ (1850) MarxEngels Werke Band 7 Berlin: Dietz-Verlag pp. 9-107

McCormick, J. P. (2011) Machiavellian Democracy Cambridge: Cambridge University Press.

Möller, K. (2017) 'Drohung und Verfahren' in T. Sheplyakova (Ed.), Prozeduralisierung des Rechts Berlin: Mohr-Siebeck (forthcoming)

Mozetic, G. (1987) Die Gesellschaftstheorie des Austromarxismus. Geistesgeschichtliche Voraussetzungen, Methodologie und soziologisches Programm Darmstadt: Wissenschaftliche Buchgesellschaft Darmstadt

Neumann, F. L. (1957) 'The Change in the Function of Law in Modern Society' (1937) in F. L. Neumann (Ed.), The Democratic and the Authoritarian State: Essays in Political and Legal Theory New York: Free Press pp. 22-68

Neumann, F. L. (1978) 'Die soziale Bedeutung der Grundrechte in der Weimarer Verfassung' (1930) Wirtschaft, Staat, Demokratie. Aufsätze 1930-1954 Frankfurt am Main: Suhrkamp pp. 57-75

Polybius. (1889) The Histories of Polybius London/New York: MacMillan and Co.

Przeworski, A. (1987) Capitalism and Social Democracy New York: Cambridge University Press

Rancière, J. (2004) Disagreement: Politics and Philosophy Minneapolis: University of Minnesota

Press

Renner, K. (1970) 'Probleme des Marxismus' (1916) in H.-J. Sandkühler \& R. De La Vega (Eds.), Austromarxismus. Texte zu "Ideologie und Klassenkampf" Frankfurt am Main: Europäische Verlagsanstalt pp. 263-301 
Saage, R. (1985) 'Restriktionsanalysen Otto Bauers am Beispiel der Ersten Österreichischen Republik' in D. Albers, H. Heimann, \& R. Saage (Eds.), Otto Bauer: Theorie und Politik Berlin: Argument-Verlag pp. 20-31

Saage, R. (2012) Zwischen Marx und Darwin. Zur Rezeption der Evolutionstheorie in der deutschen und österreichischen Sozialdemokratie vor 1933/34 Wien/Köln/Weimar: Böhlau-Verlag.

Sandner, G. (2002) 'From the Cradle to the Grave: Austro-Marxism and Cultural Studies' Cultural Studies, 16(6), doi:10.1080/0950238022000034264, pp.908-918

Sandner, G. (2005) 'Nations without Nationalism : the Austro-Marxist Discourse on Multiculturalism' Journal of Language and Politics, 4(2), 273-291

Scheuerman, W. E. (1997) Between the Norm and the Exception: The Frankfurt School and the Rule of Law Massachusetts: MIT Press

Thalheimer, A. (1972) 'Über den Faschismus' (1928) in W. Abendroth (Ed.), Faschismus und Kapitalismus. Theorie über die sozialen Ursprünge und die Funktion des Faschismus Frankfurt am Main: Europäische Verlagsanstalt pp. 19-39

Vatter, M. (2000) Between Form and Event: Machiavelli's Theory of Political Freedom Dordrecht/Boston/London: Springer

\section{Endnotes}

${ }^{1}$ I thank Hauke Brunkhorst, Philipp Schink, Leonhard Dobusch, Loren Balhorn and the reviewers of SSPT for their helpful comments. My research has received funding from the European Research Council (ERC) under the European Union's Horizon 2020 research and innovation programme (ERC2014-CoG, No. 647313).

The article is devoted to the work of Otto Bauer and the AustroMarxist current that experienced its heyday in the 1920s and 1930s. Unfortunately, literature on Austro-Marxism in English has been scarce. However, two volumes have recently been published which contain important texts and articles: Mark. E Blum and William Smaldone, eds., Austro-Marxism: The Ideology of Unity, Austro-Marxist Theory and Strategy, 
Volume 1 (Leiden: Brill, 2015); Mark. E Blum and William Smaldone, eds., Austro-Marxism: The Ideology of Unity, Changing the World: The Politics of Austro-Marxism, Volume 2 (Leiden: Brill, 2017). Before, the Anglophone reception of Austro-Marxism mainly referred to a collection of the most important texts (Tom Bottomore and Patrick Goode, eds., Austro-Marxism: Texts (Oxford: Oxford University Press, 1978), selected translations (Otto Bauer, The Austrian Revolution (London: L. Parsons, 1925); Otto Bauer, The Question of Nationalities and Social Democracy (Minneapolis/London: University of Minnesota Press, 2000) and some journal articles (Norbert Leser, 'Austro-Marxism: A Reappraisal,' Journal of Contemporary History 11 (1976), 133-48; Tom Bottomore, 'Austro-Marxist Conceptions of the Transition from Capitalism to Socialism,' International Journal of Comparative Sociology 30 (1989), 109-20; Günther Sandner, 'From the Cradle to the Grave: Austro-Marxism and Cultural Studies,' Cultural Studies 16 (2002), 908-18; Günther Sandner, 'Nations without Nationalism : the Austro-Marxist Discourse on Multiculturalism,' Journal of Language and Politics 4 (2005), 27391; Wolfgang Maderthaner, 'Austro-Marxism: Mass Culture and Anticipatory Socialism,' Austrian Studies 14 (2006), 21-36). Quotations from German are as close as possible to the original meaning. Where in doubt, the German expressions have been included.

2 'Political Marxism' in this sense does not refer to the theoretical current within the Anglophone world, but rather to a Marxism that is political, i.e. that views the production of theory as a means to an end, namely the political transformation of society as a whole.

${ }^{3}$ Polybius, The Histories of Polybius (London/New York: MacMillan and Co., 1889), p.466.

${ }^{4}$ Here my argument is indebted to Lefort's reading of Machiavelli in Claude Lefort, Le travail de l'oeuvre Machiavel (1972) (Paris: Gallimard, 1986).

${ }^{5}$ Niccolò Machiavelli, Il Principe (1532) (Stuttgart: Reclam, 2003), p.117.

${ }^{6}$ This leads to a slightly different reconstruction of the Roman Republic: As Machiavelli argued in the Discourses, the rise of the Roman Republic cannot only be seen as a mere virtue of the mixed constitution. The constitutionalisation of the fundamental discord between the populo and the grandi plays a decisive role: 'That the disunion of the plebs and the Roman 
Senate made that Republic free and powerful' (Niccolò Machiavelli, Discorsi (1531) (Frankfurt/Leipzig: Insel-Verlag, 2000)Niccolò Machiavelli, Discorsi (1531); Book I, Chapter 4, 257). For a reconstruction that reveals the primacy of conflict in Machiavelli see Miguel Vatter, Between Form and Event: Machiavelli's Theory of Political Freedom (Dordrecht/Boston/London: Springer, 2000); Claude Lefort, Le travail de l'oeuvre Machiavel (1972) and John P. McCormick, Machiavellian Democracy (Cambridge: Cambridge University Press, 2011).

${ }^{7}$ I cannot provide an encompassing picture of radical democratic theory at this point; see for approaches that draw on the Roman conflict between Plebians and Patricians: e.g. Miguel Abensour, Democracy Against the State: Marx and the Machiavellian Moment (Cambridge/Malden: Polity Press, 2011); J. Rancière, Disagreement: Politics and Philosophy (Minneapolis: University of Minnesota Press, 2004); Laclau loosely draws on this model as well: Ernesto Laclau, On Populist Reason (London/New York: Verso, 2005), 93.

${ }^{8}$ In the German language the term 'left- socialism' describes the movements and parties that evolved in opposition to both reformist Social Democracy and orthodox Communism from the 1920s onwards, see Andreas Diers and Mark Schmitz, 'Linkssozialismus,' in Historisch-kritisches Wörterbuch des Marxismus (Hamburg: Argument-Verlag, 2015).

${ }^{9}$ Claude Lefort's critique of Marx's early writings (c.f. Claude Lefort, 'Droit de l'homme et politique,' in L'invention démocratique, ed. Claude Lefort (Paris: Fayard, 1994)) proceeds in a sketchy manner and fails to take Marx's radical democratic elements into account: see e.g. how Hauke Brunkhorst, 'Kommentar,' in Karl Marx. Der achtzehnte Brumaire des Louis Bonaparte, ed. Hauke Brunkhorst (Frankfurt am Main: Suhrkamp, 2007) reveals the democratic elements in the young Marx.

${ }^{10}$ Antonio Gramsci, Gefängnishefte - kritische Gesamtausgabe (Hamburg: Argument, 1991); August Thalheimer, 'Über den Faschismus (1928), in Faschismus und Kapitalismus. Theorie über die sozialen Ursprünge und die Funktion des Faschismus, ed. Wolfgang Abendroth (Frankfurt am Main: Europäische Verlagsanstalt, 1972); Otto Kirchheimer, 'Zur Staatslehre von Sozialismus und Bolschewismus,' in Von der Weimarer Republik zum Faschismus: Die Auflösung der demokratischen Rechtsordnung, ed. Wolfgang Luthardt (Frankfurt am Main: Suhrkamp, 1976); Franz L. Neumann, 'The Change in the Function of Law in Modern Society (1937),' in The Democratic and the Authoritarian State: Essays in Political and Legal Theory, ed. Franz L. 
Neumann (New York: Free Press, 1957).

${ }^{11}$ For histories of Austro-Marxism see: Norbert Leser, Zwischen Reformismus und Bolschewismus. Der Austromarxismus als Theorie und Praxis (Wien/Frankfurt/Zürich: Europa Verlag, 1968); Gerald Mozetic, Die Gesellschaftstheorie des Austromarxismus. Geistesgeschichtliche Voraussetzungen, Methodologie und soziologisches Programm (Darmstadt: Wissenschaftliche Buchgesellschaft Darmstadt, 1987); Tom Bottomore, 'Austro-Marxist Conceptions of the Transition from Capitalism to Socialism', International Journal of Comparative Sociology Vol 30, Leiden (Jan1, 1989), p.109.

12 See Gerald Mozetic, Die Gesellschaftstheorie des Austromarxismus. Geistesgeschichtliche Voraussetzungen, Methodologie und soziologisches Programm, p.2.

${ }^{13}$ Otto Bauer, 'Austromarxismus' (1927), in Vision und Wirklichkeit. Ein Lesebuch zum Austromarxismus, ed. Alfred Pfabigan (Wien: Löcker Verlag, 1989), p.14.

${ }^{14}$ Otto Bauer, 'Austromarxismus' (1927), p.15 ff. See the interpretation in Detlev Albers, 'Über den Marxismus Otto Bauers und Antonio Gramscis,' in Sozialismus im Westen. Erste Annäherungen: Marxismus und Sozialdemokratie, ed. Detlev Albers (Berlin u. Hamburg: Argument-Verlag, 1987).

15 Friedrich Engels, 'Zur Kritik des sozialdemokratischen Programmentwurfs' (1891), in Karl Marx/Friedrich Engels - Werke Band 22 (Berlin: Dietz-Verlag, 1972), p.227.

${ }^{16}$ Karl Renner, 'Probleme des Marxismus' (1916), in Austromarxismus. Texte $z$ 'Ideologie und Klassenkampf', ed. Hans-Jörg Sandkühler and Rafael De La Vega (Frankfurt am Main: Europäische Verlagsanstalt, 1970), p.296.

${ }^{17}$ Hans Kelsen, Sozialismus und Staat. Eine Untersuchung der politischen Theorie des Marxismus (1920) (Wien: Wiener Volksbuchhandlung, 1965), p.170 ff.

${ }^{18}$ See the conception of 'balance of class forces' in the democratic republic in: Otto Bauer, 'Das Gleichgewicht der Klassenkräfte (1924),' in Austromarxismus, Texte zu 'Ideologie und Klassenkampf', ed. Hans-Jörg Sandkühler and Rafael De La Vega (Frankfurt am Main: Europäische Verlagsanstalt, 1970). 
19 Otto Bauer, Die österreichische Revolution (Wien: Wiener Volksbuchhandlung, 1923), p.288.

${ }^{20}$ Detlev Albers, 'Anmerkungen zur Aktualität Otto Bauers und des Austromarxismus in Otto Bauer - Theorie und Politik, ed. Detlev Albers, Horst Heimann, and Richard Saage (Berlin: Argument-Verlag, 1985), p.139.

${ }^{21}$ See: Detlev Albers, 'Über den Marxismus Otto Bauers und Antonio Gramscis' and Wolfgang Maderthaner, 'Austro-Marxism: Mass Culture and Anticipatory Socialism', p.29.

22 Max Adler, 'Der Klassenkampfgedanke bei Marx (1923)', in Austromarxismus, Texte zu 'Ideologie und Klassenkampf', ed. Hans-Jörg Sandkühler and Rafael De La Vega (Frankfurt am Main: Europäische Verlagsanstalt, 1970), p.151.

${ }^{23}$ See Maderthaner's reconstruction of Austro-Marxism as 'anticipatory socialism' in: Wolfgang Maderthaner, 'Austro-Marxism: Mass Culture and Anticipatory Socialism'; for the strategies of transition see Tom Bottomore, 'Austro-Marxist Conceptions of the Transition from Capitalism to Socialism'.

${ }^{24}$ Otto Bauer, Zwischen zwei Weltkriegen. Die Krise der Weltwirtschaft, die Demokratie und der Sozialismus (Bratislava: Eugen Prager Verlag, 1936), 234; for the context and history of this idea see Walter Baier, 'Integraler Sozialismus und radikale Demokratie,' in Otto Bauer und der Austromarxismus. 'Integraler Sozialismus' und die heutige Linke, ed. Walter Baier, Lisbeth N. Trallori, and Derek Weber (Berlin: Dietz-Verlag, 2008), Detlev Albers, 'Über den Marxismus Otto Bauers und Antonio Gramscis'; Detlev Albers, 'Otto Bauer und des Konzept des 'integralen Sozialismus,' in Eurokommunismus und Theorie der Politik, ed. Arbeitskreis Westeuropäische Arbeiterbewegung (Berlin: Argument-Verlag, 1979).

${ }^{25}$ Otto Bauer, 'Das Gleichgewicht der Klassenkräfte' (1924), p.92.

${ }^{26}$ This is how Hans Kelsen interprets Marx' conception of dictatorship, see Hans Kelsen, Sozialismus und Staat. Eine Untersuchung der politischen Theorie des Marxismus (1920), 59; for a genealogy of the discussion on the dictatorship of the proletariat in the 19th century, emphasizing its rather 'Roman use', see Hal Draper, Karl Marx's Theory of Revolution: The Dictatorship of the Proletariat (New York: Monthly Review Press, 1986). 
27 Though Bauer's account is quite sensitive to the plurality of social struggles, see Volker Gransow and Michael Krätke, 'Thesen zur politischen Theorie des Austromarxismus,' in Eurokommunismus und Theorie der Politik, ed. Arbeitskreis Westeuropäische Arbeiterbewegung (Berlin: ArgumentVerlag, 1979), p.103 ff.

${ }^{28}$ Cf. Richard Saage, 'Restriktionsanalysen Otto Bauers am Beispiel der Ersten Österreichischen Republik,' in Otto Bauer: Theorie und Politik, ed. Detlev Albers, Horst Heimann, and Richard Saage (Berlin: Argument-Verlag, 1985), p.20.

${ }^{29}$ Otto Bauer, Die österreichische Revolution, p.99.

${ }^{30}$ Otto Bauer, Die österreichische Revolution, p.126.

${ }^{31}$ Otto Bauer, Die österreichische Revolution, p.126.

${ }^{32}$ Government Renner I 30 October 1918 - 15 march 1919, in this period Bauer was the minister of foreign affairs. He stayed in office until july 1919, cf. Ernst Hanisch, Der große Ilusionist. Otto Bauer (1881-1938) (Wien/Köln/Weimar: Böhlau-Verlag, 2011), 148 ff.

${ }^{33}$ Otto Bauer, Die österreichische Revolution, p.116 ff.

${ }^{34}$ Otto Bauer, 'Demokratie und Sozialismus' (1934), p.105 ff.

${ }^{35}$ Otto Bauer, Die österreichische Revolution, p.188.

${ }^{36}$ Otto Bauer, Die österreichische Revolution, p.128.

${ }^{37}$ Otto Bauer, Die österreichische Revolution, p.188.

${ }^{38}$ Otto Bauer, Die österreichische Revolution, p.181.

${ }^{39}$ Otto Bauer, Die österreichische Revolution, p.181.

${ }^{40}$ Otto Bauer, Die österreichische Revolution, p.186.

${ }^{41}$ Otto Bauer, Die österreichische Revolution, p.127.

${ }^{42}$ Otto Bauer, 'Demokratie und Sozialismus' (1934), p.113. 
${ }^{43}$ Otto Bauer, Die österreichische Revolution, p.196 ff.

${ }^{44}$ Otto Bauer, Die österreichische Revolution, p.204.

${ }^{45}$ Government Renner II (15 march - 17 October 1919).

${ }^{46}$ Friedrich Engels, 'Der Ursprung der Familie, des Privateigentums und des Staats (1884),' in Karl Marx/Friedrich Engels - Werke Band 21 (Berlin: DietzVerlag, 1975), p.484f.

${ }^{47}$ Otto Bauer, 'Das Gleichgewicht der Klassenkräfte' (1924), 79; for a similar argument with regard to inter-war constitutionalism in Germany see Franz L. Neumann, 'Die soziale Bedeutung der Grundrechte in der Weimarer Verfassung (1930),' in Wirtschaft, Staat, Demokratie. Aufsätze 1930-1954, (Frankfurt am Main: Suhrkamp, 1978); Otto Kirchheimer, 'Zur Staatslehre von Sozialismus und Bolschewismus'. With regard to the post-war constitution in Germany see Wolfgang Abendroth, 'Zum Begriff des demokratischen und sozialen Rechtsstaates im Grundgesetz der Bundesrepublik Deutschland' (1954), in Gesammelte Schriften Band 2, ed. Michael Buckmiller, Joachim Perels, and Uli Schöler (Hannover: Offizin, 2008).

${ }^{48}$ Otto Bauer, Die österreichische Revolution, p.245.

${ }^{49}$ Otto Bauer, Die österreichische Revolution, 290; see also Kelsen's critique of Bauer: To Kelsen 'it is of minor importance if the social relation of class forces is formally expressed in a coalition government' (Hans Kelsen, 'Otto Bauers politische Theorien' (1924), in Austromarxistische Positionen, ed. Gerald Mozetic (Wien/Köln/Graz/Böhlau: Hermann Böhlaus Nachf., 1983), p.212.

${ }^{50}$ Otto Bauer, Die österreichische Revolution, p.280.

${ }^{51}$ Cf. Richard Saage, Zwischen Marx und Darwin. Zur Rezeption der Evolutionstheorie in der deutschen und österreichischen Sozialdemokratie vor 1933/34 (Wien/Köln/Weimar: Böhlau-Verlag, 2012); Ernst Hanisch, Der große Ilusionist. Otto Bauer (1881-1938), p.112 ff.

${ }^{52}$ Otto Bauer, 'Demokratie und Sozialismus' (1934), p.102. However, this assumption proved wrong in many countries: Adam Przeworski, Capitalism and Social Democracy (New York: Cambridge University Press, 1987), p.16 ff. 
${ }^{53}$ Wolfgang Maderthaner, 'Austro-Marxism: Mass Culture and Anticipatory Socialism'

${ }^{54}$ See Hal Draper, Karl Marx's Theory of Revolution: The Dictatorship of the Proletariat.

${ }^{55}$ Otto Bauer, 'Demokratie und Sozialismus' (1934), p.107.

${ }^{56}$ This could be considered as a negative variety of what Kalyvas called 'democratic extraordinary politics': see Andreas Kalyvas, Democracy and the Politics of the Extraordinary. Max Weber, Carl Schmitt and Hannah Arendt (New York: Cambridge University Press, 2008), p.6 ff.

${ }^{57}$ Otto Bauer, 'Demokratie und Sozialismus' (1934), p.107.

${ }^{58}$ For Marx' metaphor of revolutions as the 'locomotive of history' see Karl Marx, 'Die Klassenkämpfe in Frankreich 1848 bis 1850 (1850),' in Marx-Engels Werke Band 7 (Berlin: Dietz-Verlag, 1960), 110; for the revolution as emergency brake: 'Marx said that revolutions are the locomotive of world history. But perhaps things are very different. It may be that revolutions are the act by which the human race travelling in the train applies the emergency brake.' Walter Benjamin, 'Notizen und Vorarbeiten zu den Thesen, 'Über den Begriff der Geschichte' in Gesammelte Werke I/3 (Frankfurt am Main: Suhrkamp, 1974), p.402.

${ }^{59}$ See Frank Heidenreich, 'Das Linzer Programm und die Strategie des demokratischen Wegs zum Sozialismus,' in Otto Bauer: Theorie und Politik, ed. Detlev Albers, Horst Heimann, and Richard Saage (Berlin: ArgumentVerlag, 1985); Ernst Hanisch, Der große Ilusionist. Otto Bauer (1881-1938), p.230 ff.

${ }^{60}$ For a critical perspective on the role of the social democratic party see Norbert Leser, Zwischen Reformismus und Bolschewismus. Der Austromarxismus als Theorie und Praxis, (Wien/Frankfurt/Zürich: Europa Verlag, 1968), p.470.

${ }^{61}$ The left critique was formulated by Ilona Duczynska, Der demokratische Bolschewik. Zur Theorie und Praxis der Gewalt (München: List Verlag, 1975): 'The Schutzbund was never meant for such an intervention, but as a gesture of threat. The mere existence of such a para-military formation [...] should keep reactionary forces and fascism as long as possible at bay' (222); for the right critique see Norbert Leser, Zwischen Reformismus und Bolschewismus. 
Der Austromarxismus als Theorie und Praxis: 'The Linzer Programm stood nearer to a meritocratic right to resistance as to Marxist theory, which it used to legitimize a matter of course.' p.398.

${ }^{62}$ Hans Kelsen, ‘Otto Bauers politische Theorien' (1924) p.205.

${ }^{63}$ This may be a lingering problem in all politics of threat, see for a more detailed investigation: Kolja Möller, 'Drohung und Verfahren,' in Prozeduralisierung des Rechts, ed. Tatjana Sheplyakova (Berlin: Mohr-Siebeck, 2017).

${ }^{64}$ Ilona Duczynska, Der demokratische Bolschewik. Zur Theorie und Praxis der Gewalt, (München: List Verlag, 1975) p.222.

${ }^{65}$ Ilona Duczynska, Der demokratische Bolschewik. Zur Theorie und Praxis der Gewalt, (München: List Verlag, 1975) p.70.

${ }^{66}$ Cited in: Norbert Leser, Zwischen Reformismus und Bolschewismus. Der Austromarxismus als Theorie und Praxis, (Wien/Frankfurt/Zürich: Europa Verlag, 1968) p.155.

${ }^{67}$ See e.g. Otto Bauer, Die österreichische Revolution, p.186.

${ }^{68}$ This approximates Bauer to the critical theory of the rule of law which surrounded the early Frankfurt School; see e.g. Otto Kirchheimer, 'Zur Staatslehre von Sozialismus und Bolschewismus'; William E. Scheuerman, Between the Norm and the Exception: The Frankfurt School and the Rule of Law (Massachusetts: MIT Press, 1997).

${ }^{69}$ Susan George, Shadow Sovereigns: How Global Corporations are Seizing Power (Cambridge/Malden: Polity Press, 2015). 